This item was submitted to Loughborough's Research Repository by the author.

Items in Figshare are protected by copyright, with all rights reserved, unless otherwise indicated.

\title{
An $\mathrm{Au}(\mathrm{I})$-catalysed allenamide cyclisation giving access to an $\alpha$-vinyl- substituted tetrahydroisoquinoline building block
}

PLEASE CITE THE PUBLISHED VERSION

http://www.thieme-connect.com

PUBLISHER

(c) Georg Thieme Verlag

VERSION

AM (Accepted Manuscript)

LICENCE

CC BY-NC-ND 4.0

\section{REPOSITORY RECORD}

Singh, Sanjitpal, Mark R.J. Elsegood, and Marc C. Kimber. 2019. "An Au(i)-catalysed Allenamide Cyclisation Giving Access to an A-vinyl-substituted Tetrahydroisoquinoline Building Block”. figshare.

https://hdl.handle.net/2134/13935. 
This item was submitted to Loughborough's Institutional Repository (https://dspace.lboro.ac.uk/) by the author and is made available under the following Creative Commons Licence conditions.

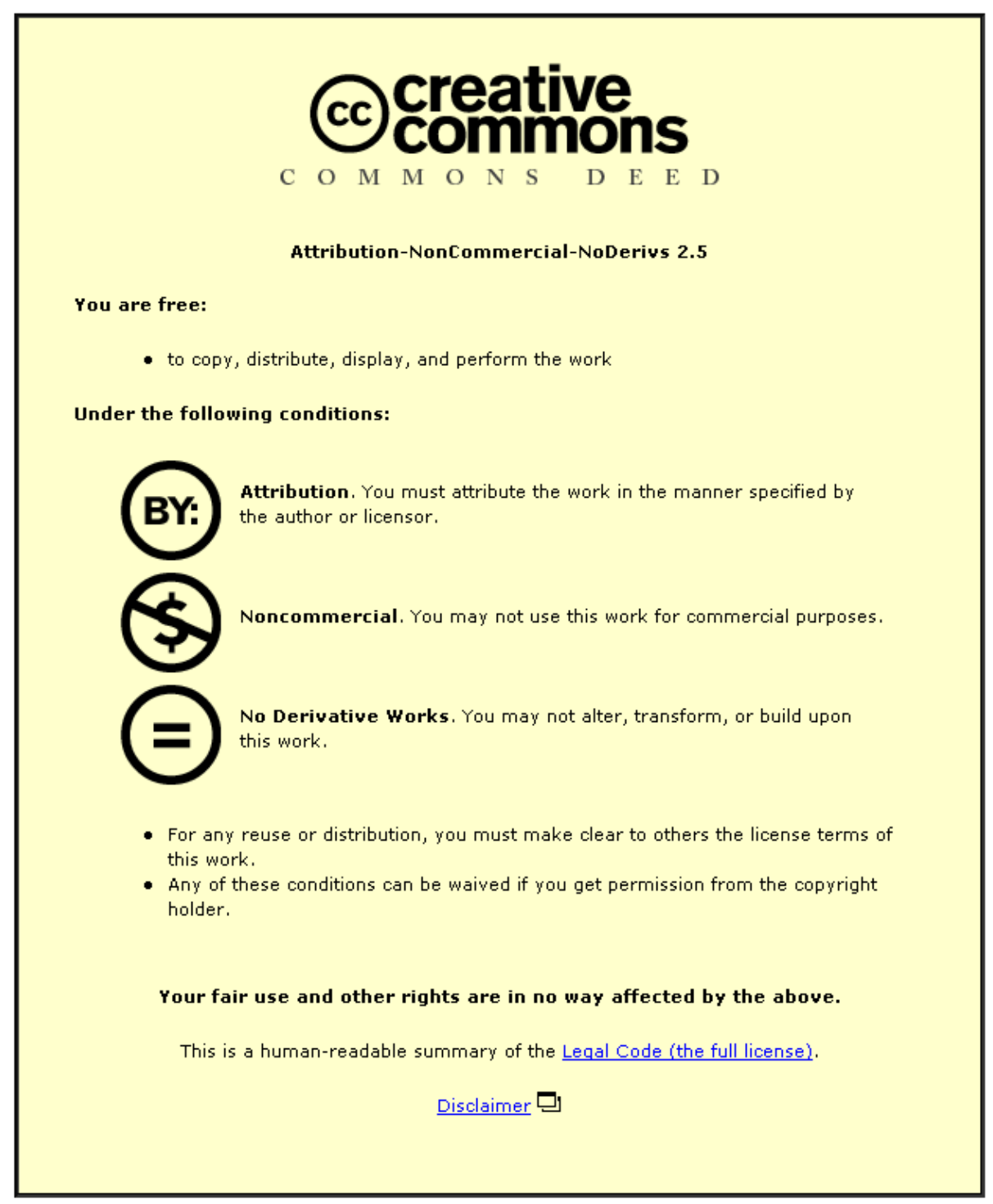

For the full text of this licence, please go to: http://creativecommons.org/licenses/by-nc-nd/2.5/ 


\title{
An $\mathrm{Au}(\mathrm{I})$ catalysed allenamide cyclisation giving access to a $\alpha$-vinyl substituted tetrahydroisoquinoline building block
}

\author{
Sanjitpal Singh, Mark R. J. Elsegood, and Marc C. Kimber* \\ The Department of Chemistry, Loughborough University, Loughborough, Leicester, LE11 3TU, UK \\ Fax: +44(0)-150-922-3925 \\ E-mail: M.C.Kimber@lboro.ac.uk \\ Received: The date will be inserted once the manuscript is accepted.
}

Abstract: $\mathrm{An} \mathrm{Au}(\mathrm{I})$ catalysed intramolecular hydroarylation of an enantiopure allenamide has been achieved and has given access to a key $\alpha$-vinyl substititued tetrahydroisoquinoline. Additionally this has been accomplished in very high yield and high diastereoselectivity.

Key words: Alkaloids, allenamide, tetrahydroisoquinoline, $\mathrm{Au}(\mathrm{I})$-catalysis, diastereoselective.

Tetrahydroisoquinolines are highly significant synthetic subunits contained within many biologically active alkaloids (Figure 1). ${ }^{1}$ Contained within many of these alkaloids is a stereogenic centre at the $\alpha$-position on the ring which is commonly installed, either enantio- or diastereoselectively, via a Pictet-Spengler ${ }^{2}$ or BischelerNapieralski ${ }^{3}$ condensations. ${ }^{4}$ Ideally, a key synthetic building block for the total synthesis of such targets would be the $\alpha$-vinyl substituted tetrahydroisoquinoline $\mathbf{4}$, since the vinyl group can be readily manipulated (Scheme 1).,
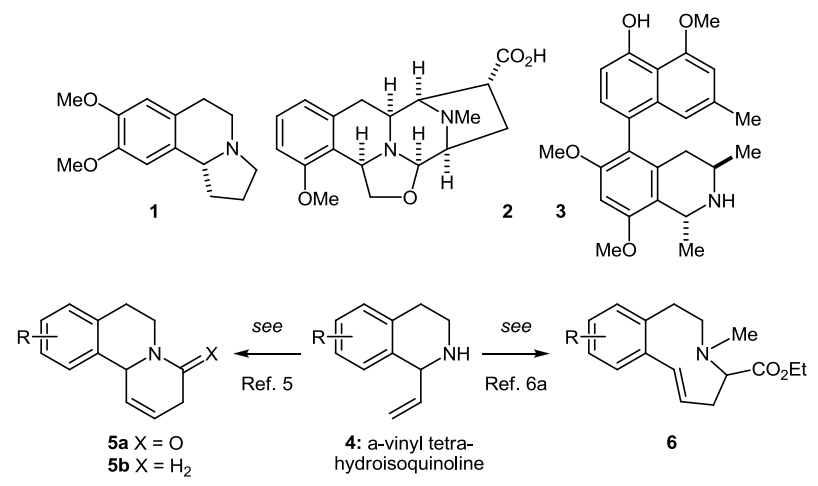

Scheme 1. Tetrahydroisoquinoline natural products crispine A (1), quinocarcin (2), korumpensamine (3) and $\alpha$-vinyl tetrahydroisoquinoline building block (4) and its known conversion to 5 and 6 .

However, access to $\alpha$-vinyl substituted tetrahydroisoquinolines using the Pictet-Spengler or Bischler-Napieralski approaches is somewhat problematic and therefore unsuitable. ${ }^{5}$ To overcome this chemical issue a number of approaches have been disclosed, including; (a) vinyl organometallic addition to suitable quinoline substrates, ${ }^{6}$ (b) Pd-catalysed addition to allenamides, ${ }^{7}$ (c) iridium $^{8 \mathrm{a}}$ and palladium $^{8 \mathrm{~b}}$ catalysed intramolecular allylic amination, and finally, (d) an intramolecular hydroarylation on a masked conjugated $N$-acyl iminium species (Scheme
2), ${ }^{5,9}$ and it is this last approach that is the focus of this letter.

In 2005 Rutjes $^{5}$ reported a synthetically flexible route to $\alpha$ vinyl substituted tetrahydroisoquinoline building blocks (10) via a $\mathrm{Sn}$ (II) or TFA catalysed cyclisation of allylic N,O-acetals (7). This was followed in 2007 by NavarroVazquez and Dominquez ${ }^{9}$ who elegantly illustrated that allenamides $(\mathbf{8})$ could be cyclised under acidic condition to yield $\alpha$-vinyl substituted tetrahydroisoquinolines (10) in good yield. While both authors used a masked conjugated $N$-acyl iminium (9) to generate their $\alpha$-vinyl tetrahydroisoquinoline substrates $(\mathbf{1 0})$, it was only the work of Rutjes who investigated any diastereoselectivity in their transformation, which was found to be modest.

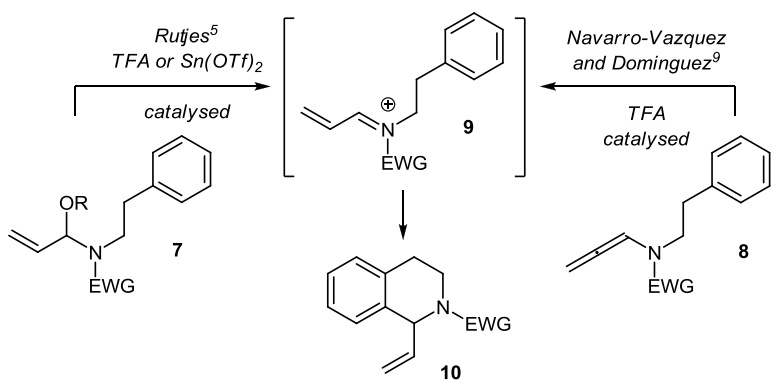

Scheme 2. Previous $N$-acyl iminium approaches to $\alpha$-vinyl tetrahydroisoquinolines

Recently, we described the $\mathrm{Au}(\mathrm{I})$ activation of allenamides ${ }^{10}$ and their subsequent reaction with electron rich arenes and arylamines to yield functionalised enamide building blocks (Scheme 3). ${ }^{11}$ This approach to allenamide activation, ${ }^{12}$ under such mild conditions, led us to consider whether an intramolecular arene cyclisation could be accomplished. Therefore, in this brief Letter we would like to disclose a concise and yet highly diastereoselective route to a key $\alpha$ vinyl substituted tetrahydroisoquinoline building blocks.
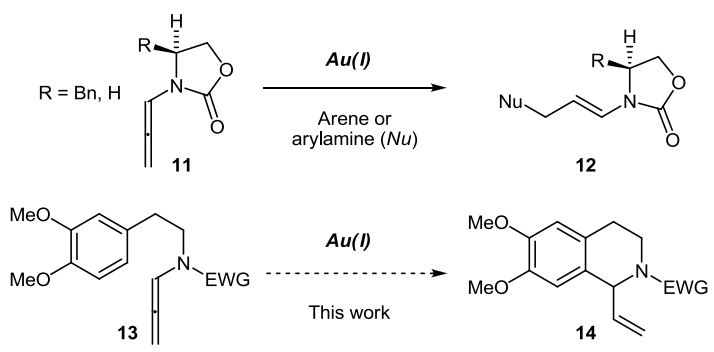

Scheme 3. 
To test our approach to $\mathrm{Au}(\mathrm{I})$-catalysed intramolecular cyclisation we synthesised allenamide $\mathbf{1 7}$ in two steps from the known acid 15 (Scheme 4). Allenamide 17 was then exposed to a variety of cyclisation conditions as shown in Table 1 .<smiles>COc1ccc(CC(=O)O)cc1OC</smiles><smiles>C#CCN(C)C(=O)Cc1ccc(OC)c(OC)c1</smiles><smiles>C=CC1c2cc(OC)c(OC)cc2CC(=O)N1C</smiles><smiles>C=CCN(C)C(=O)Cc1ccc(OC)c(OC)c1</smiles>

Scheme 4. (a) DCC, $\mathrm{CH}_{2} \mathrm{Cl}_{2}$, DMAP, $N$-methylpropargyl amine; (b) THF, $\mathrm{KO}^{t} \mathrm{Bu}[75 \%$ over 2 -steps].

Table 1. Conditions for the intramolecular cyclisation of $\mathbf{1 7}$ to 18. ${ }^{a}$

\begin{tabular}{ccccc}
\hline Entry & Catalyst & Temp. $\left({ }^{\circ} \mathrm{C}\right)$ & $\mathrm{T}(\mathrm{h})$ & Yield $(\%)^{b}$ \\
\hline 1 & $\mathrm{AuPPh}_{3} \mathrm{OTf}$ & r.t. & 1 & 95 \\
2 & $\mathrm{AuPPh}_{3} \mathrm{NTf}_{2}$ & 35 & 16 & 91 \\
3 & $\mathrm{AgOTf}$ & r.t. & 16 & s.m. \\
4 & $\mathrm{TFA}^{c}$ & r.t. & 16 & decomp. \\
5 & $\mathrm{AuPPh}_{3} \mathrm{OTf}^{d}$ & r.t. & 16 & 96
\end{tabular}

${ }^{a}$ All reactions were performed under an atmosphere of $\mathrm{N}_{2}$ unless otherwise stated and with $5 \mathrm{~mol} \%$ catalysts unless otherwise states. ${ }^{b}$ Isolated yield. ${ }^{c} 20 \mathrm{~mol} \%{ }^{d} 2.5 \mathrm{~mol} \%$.

Exposure of 17 to $5 \mathrm{~mol} \% \mathrm{AuPPh}_{3} \mathrm{OTf}$ gave the desired intramolecular cyclisation product in an excellent yield with tlc showing full consumption of the starting material within an hour (entry 1). A switch to the $\mathrm{AuPPh}_{3} \mathrm{NTf}_{2}$ did give the desired product but the reaction time was extended considerably (entry 2). To show the requirement of $\mathrm{Au}(\mathrm{I})$ catalysts the reaction was undertaken with AgOTf which gave only starting material (entry 3), while TFA did catalyse the reaction but gave predominantly decomposition products (entry 4). Finally, we decreased the catalysts loading of $\mathrm{AuPPh}_{3} \mathrm{OTf}$ to $2.5 \mathrm{~mol} \%$ which furnished the cyclized product in $96 \%$ yield but required an extended reaction time as compared to entry 1 .

With result in hand we then investigated the cyclisation the Boc protected allenamide 21 which was synthesized in 3steps from the known acid $\mathbf{1 9}$ (Scheme 5). Unfortunately, exposure of this substrate to our $\mathrm{Au}(\mathrm{I})$ catalyzed cyclisation conditions, failed to deliver any of the desired product with only starting material being returned. We believe that this maybe a consequence of the bulky Boc protecting group contained within $\mathbf{2 1}$ hampering activation of the allenamide by the $\mathrm{Au}(\mathrm{I})$ catalyst.

Consequently, based on our previous investigations on intermolecular allenamide activation we targeted an oxazolidinone protected allenamide $\mathbf{2 2}$ as a Boc surrogate.

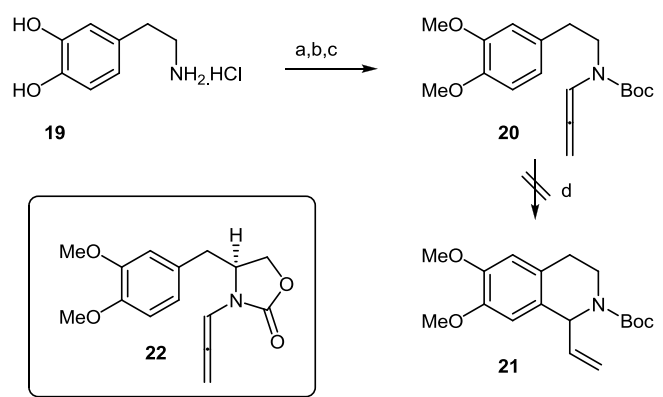

Scheme 5. (a) $\mathrm{Boc}_{2} \mathrm{O}, \mathrm{NEt}_{3}, \mathrm{H}_{2} \mathrm{O}$, dioxane; (b) $\mathrm{MeI}, \mathrm{K}_{2} \mathrm{CO}_{3}, \mathrm{DMF}$; $\mathrm{NaH}$; (c) $\mathrm{KO}^{t} \mathrm{Bu}$, propargyl bromide [60\% over 3 -steps]; (d) $\mathrm{AuPPh}_{3} \mathrm{OTf}$ or $\mathrm{AuPPh}_{3} \mathrm{NTf}_{2}(5 \mathrm{~mol} \%), \mathrm{CH}_{2} \mathrm{Cl}_{2}$, rt or reflux, $16 \mathrm{~h}$.

The synthesis began with conversion of $L$-DOPA (13) to its Boc protected methyl ester under standard conditions, followed by global methylation with $\mathrm{MeI}$ and $\mathrm{K}_{2} \mathrm{CO}_{3}$ to give 14 in $92 \%$ overall yield over the 3 -steps. Subsequent $\mathrm{LiBH}_{4}$ reduction of 14 and treatment of the crude product with thionyl chloride in THF delivered the oxazolidinone $\mathbf{1 5}$ in $88 \%$ yield over the 2 -steps. Finally, $\mathbf{1 5}$ was alkylated with propargyl bromide to furnish the alkyne $\mathbf{1 6}$ which could then be rearranged under basic conditions to give the desired chiral allenamide 22 in $62 \%$ yield. ${ }^{13}$ Alternatively, treatment of $\mathbf{1 5}$ under modified Heaney/Ley conditions ${ }^{14}$ with propargyl bromide directly gave 22 in $60 \%$ yield. Allenamide $\mathbf{2 2}$ proved to be crystalline and crystals suitable for single crystal X-ray analysis were obtained. The X-ray ${ }^{15-}$ ${ }^{18}$ depiction is shown below in Scheme $6 .{ }^{19}$

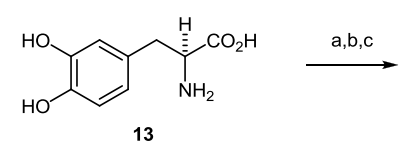<smiles>COc1ccc(CC(NC(C)=O)C(C)=O)cc1OC</smiles><smiles>C#CCN1C(=O)OC[C@H]1Cc1ccc(OC)c(OC)c1</smiles><smiles>CC(C)(C)C</smiles><smiles>COc1ccc(C[C@@H]2COC(=O)N2)cc1OC</smiles><smiles>C=CCN1C(=O)OC[C@H]1Cc1ccc(OC)c(OC)c1</smiles><smiles>[Y4]O[R10][H]</smiles>

Scheme 6. (a) $\mathrm{MeOH}, \mathrm{SOCl}_{2}$; (b) $\mathrm{Boc}_{2} \mathrm{O}, \mathrm{Et}_{3} \mathrm{~N}, \mathrm{MeOH}$; (c) $\mathrm{MeI}$, $\mathrm{K}_{2} \mathrm{CO}_{3}$, DMF [92\% over 3-steps]; (d) $\mathrm{LiBH}_{4}$, THF; (e) $\mathrm{SOCl}_{2}$, THF [88\% over 2-steps]; (f) $\mathrm{NaH}$, propargyl bromide ( $80 \%$ in hexane); (g) $\mathrm{KO}^{t} \mathrm{Bu}, \mathrm{THF}\left[62 \%\right.$ over 2 -steps]; (h) $\mathrm{KO}^{t} \mathrm{Bu}$, propargyl bromide (80\% in hexane), DMSO [60\%].

Treatment of 22 with $\mathrm{AuPPh}_{3} \mathrm{OTf}\left(5 \mathrm{~mol} \%\right.$ ) in $\mathrm{CH}_{2} \mathrm{Cl}_{2}$ delivered a single product $\mathbf{2 3}$ in quantitative yield. ${ }^{20}$ The reaction time was remarkably short, with the reaction completion within minutes of the addition of the $\mathrm{Au}(\mathrm{I})$ salt, indicating a very facile reaction. Exhaustive NMR analysis indicated a single product with a $d e>98 \%$ and with an 
absolute stereochemistry as shown in Scheme 7. The relative stereochemistry of the product was assigned on the basis of a NOESY enhancement between $\mathrm{H}_{3}$ and the vinylic $\mathrm{H}_{2}$, proton.

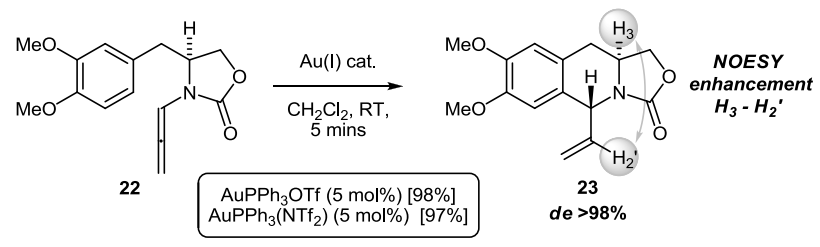

Scheme 7. $\mathrm{Au}(\mathrm{I})$ catalysed cyclisation of 22

Treatment of allenamide 22 with $\mathrm{AuPPh}_{3} \mathrm{NTf}_{2}$ (5 mol\%) also gave the tetrahydroisoquinoline $\mathbf{2 3}$ quantitatively and in excellent de. It must be noted this high diastereoselectivity is in contrast to the moderate $d e$ 's reported by Rutjes ${ }^{5}$ for similar cyclisations, and the high yield is a significant improvement over that reported by Navarro-Vazquez and Dominquez ${ }^{9}$ for their TFA catalysed cyclisations of allenamides.

In summary, a brief, yet high yielding synthesis of a key $\alpha$-vinyl substituted tetrahydroisoquinoline has been achieved. The key step was an $\mathrm{Au}(\mathrm{I})$-catalysed hydroarylation of a chiral pool derived allenamide delivering the key building block in high diastereoselectivity. Use of this building block and this synthetic approach for the synthesis of alkaloid natural products is currently under investigation.

Supporting Information for this article include ${ }^{1} \mathrm{H}$ and ${ }^{13} \mathrm{C}$ NMR of $\mathbf{2 2}$ and $\mathbf{2 3}$ and the Crystallographic data for $\mathbf{2 2}$.

\section{Acknowledgments}

The authors thank Loughborough University for funding and Mark Edgar for NMR analysis.

\section{References and Notes}

(1) For reviews on tetrahydroisoquinoline natural products and their synthesis see, (a) Cuevas, C.; Francesch, A. Nat. Prod. Rep. 2009, 26, 322; (b) Siengalewicz, P.; Rinner, U.; Mulzer, J. Chem. Soc. Rev. 2008, 37, 2676; (c) Chrzanowska, M.; Rozwadowska, M. D. Chem. Rev. 2004, 104, 3341; (d) Scott, J. D.; Williams, R. M. Chem. Rev. 2002, 102, 1669.

(2) Pictet, A.; Spengler, T. Ber. Dtsch. Chem. Ges. 1911, 44, 2030.

(3) Fodor. G.; Nagubandi, S. Tetrahedron 1980, 36, 1279.

(4) For recent selected reviews on the Pictet-Spengler reaction see, (a) Pulka, K. Curr. Op. Drug Dis. Dev. 2010, 13, 669; (b) Lorenz, Michael; Van Linn, Michael L.; Cook, James M. Curr. Org. Synth. 2010, 7, 189.

(5) For an account of this chemical issue see, Kinderman, S. S.; Wekking, M. M. T.; van Maarseveen, J. H.; Schoemaker, H. E.; Hiemstra, H., Rutjes, F. P. J. T. J. Org. Chem. 2005, 70, 5519 and references contained within.

(6) For examples see, (a) Bailey, T. S.; Bremner, J. B.; Carver, J. A. Tetrahedron Lett. 1993, 34, 3331; (b) Andersson, P. G.; Johansson, F.; Tanner, D. Tetrahedron, 1998, 54, 11549 .
(7) (a) Griggs, R.; Sansano, J. M. Tetrahedron, 1996, 52, 13441.; (b) Evans, P.; Griggs, R.; Imran Ramzan, M.; Sridharan, V.; York, M. Tetrahedron Lett. 1999, 40, 3021.

(8) (a) Teichert, J. F.; Fañanás-Mastral, M.; Feringa, B. L. Angew. Chem. Int. Ed. 2011, 50, 688; (b) Lin, C. -F.; Ojima, I. J. Org. Chem. 2011, 76, 6240.

(9) Navarro-Vásquez, A.; Rodríguez, D.; Martínez-Esperón, M. F.; García, A.; Saá, C.; Domínguez, D. Tetrahedron Lett. 2007, 48, 2741.

(10) For recent reviews on allenamides see, (a) Wei, L.-L.; Xiong, H.; Hsung, R. P. Acc. Chem. Res. 2003, 36. 773; (b) Deagostino, A.; Prandi, C.; Tabasso, S.; Venturello, P. Molecules, 2010, 15, 2667; (c) Standen, P.; Kimber, M. C. Curr. Op. Drug Dis. Dev. 2010, 13, 645.

(11) (a) Kimber, M. C. Org. Lett. 2010, 12, 1128; (b) Hill, A. W.; Elsegood, M. R. J.; Kimber, M. C. J. Org. Chem. 2010, $75,5406$.

(12) For other examples of $\mathrm{Au}(\mathrm{I})$ catalysed cyclisations of allenamides see, (a) Hyland, C. J. T.; Hegedus, L. S. J. Org. Chem. 2006, 71, 8658. (b) Manzo, A. M.; Perboni, A. D.; Broggini, G.; Rigamonti, M. Tetrahedron Lett. 2009, 50, 4696. (c) Faustino, H.; López, F.; Castedo, L.; Mascareñas, J. L. Chem. Sci. 2011, 2, 633.

(13) (S)-4-(3,4-Dimethoxybenzyl)-3-(propa-1,2-dienyl) oxazolidin-2-one 22. To a solution of 15 (0.58 g, 2.45 $\mathrm{mmol})$ in THF $(20 \mathrm{~mL})$ at $0^{\circ} \mathrm{C}$ under a $\mathrm{N}_{2}$ atmosphere was added $\mathrm{NaH}(0.12 \mathrm{~g}, 2.93 \mathrm{mmol})$ and the mixture stirred at room temperature for $2 \mathrm{~h}$. After this period propargyl bromide $(0.32 \mathrm{~mL}, 2.88 \mathrm{mmol})$ was added cautiously and the reaction mixture stirred for a further $24 \mathrm{~h}$ at room temperature. After this period sat. $\mathrm{NH}_{4} \mathrm{Cl}$ was added and the resultant aqueous layer extracted with $\mathrm{Et}_{2} \mathrm{O}(\mathrm{x} 2)$. The combined organic layers were then washed with brine, dried $\left(\mathrm{Na}_{2} \mathrm{SO}_{4}\right)$, filtered and the solvent removed in vacuo. The crude product was then dissolved in THF $(20 \mathrm{~mL})$ and cooled to $0^{\circ} \mathrm{C}$ followed by addition of ${ }^{t} \mathrm{BuOK}(0.08 \mathrm{~g}, 0.66 \mathrm{mmol})$. The reaction mixture was then stirred for $2 \mathrm{~h}$ at $0^{\circ} \mathrm{C}$ after which all the starting material had been consumed. The reaction mixture was then diluted with $\mathrm{Et}_{2} \mathrm{O}$ and washed sequentially with $\mathrm{H}_{2} \mathrm{O}$ and brine. The combined organic layers were then dried $\left(\mathrm{Na}_{2} \mathrm{SO}_{4}\right)$, filtered and the solvent removed in vacuo. The crude product was then purified by column chromatography $\left(\mathrm{R}_{\mathrm{f}}=0.55,1: 1\right.$ ethyl acetate - petroleum ether) yielding the title compound as a colourless solid $(0.40 \mathrm{~g}, 60 \%)$, m.p. $118-120^{\circ} \mathrm{C}$ from $\mathrm{CH}_{2} \mathrm{Cl}_{2}$ - petroleum ether; $v_{\max }$ (solution, $\mathrm{CHCl}_{3}$ ) 3021 , $1752,1516,1461,1409,1262,1226,1028 \mathrm{~cm}^{-1} ; \delta_{\mathrm{H}}(400$ $\left.\mathrm{MHz} ; \mathrm{CDCl}_{3}\right) 6.84(\mathrm{t}, J=6.8 \mathrm{~Hz}, 1 \mathrm{H}), 6.76-6.73(\mathrm{~m}$, $1 \mathrm{H}), 6.64-6.62(\mathrm{~m}, 1 \mathrm{H}), 6.58(\mathrm{~d}, J=1.6 \mathrm{~Hz}, 1 \mathrm{H}), 5.51$ $(\mathrm{dd}, J=6.4,10.0 \mathrm{~Hz}, 1 \mathrm{H}), 5.44(\mathrm{dd}, J=6.4,10.0 \mathrm{~Hz}$, $1 \mathrm{H}), 4.20(\mathrm{t}, J=8.4 \mathrm{~Hz}, 1 \mathrm{H}), 4.08(\mathrm{dd}, J=3.6,8.8 \mathrm{~Hz}$, $1 \mathrm{H}), 4.05-4.00(\mathrm{~m}, 1 \mathrm{H}), 3.80(\mathrm{~s}, 3 \mathrm{H}), 3.79(\mathrm{~s}, 3 \mathrm{H})$, $3.06(\mathrm{dd}, J=3.2,14.0 \mathrm{~Hz}, 1 \mathrm{H}), 2.65(\mathrm{dd}, J=8.8,14.0$ $\mathrm{Hz}, 1 \mathrm{H}) ; \delta_{\mathrm{C}}\left(100 \mathrm{MHz} ; \mathrm{CDCl}_{3}\right)$ 201.7(C), 155.0(C), 149.2(C), 148.3(C), 127.7(C), 121.4(CH), 112.4(CH), 111.5(CH), $111.5(\mathrm{CH}), \quad 96.00(\mathrm{CH}), \quad 87.9\left(\mathrm{CH}_{2}\right)$, 66.6 $\left(\mathrm{CH}_{2}\right)$, 56.0 $\left(\mathrm{CH}_{3}\right)$, 55.7 $\left(\mathrm{CH}_{3}\right), 36.6\left(\mathrm{CH}_{2}\right)$; HRMS $\mathrm{MNa}^{+}, \mathrm{C}_{15} \mathrm{H}_{17} \mathrm{NO}_{4}$, found 298.1045 , requires $\mathrm{MNa}^{+}$ 298.1055; $[\alpha]^{21}{ }_{\mathrm{D}}+20.3\left(\right.$ c $\left.1.00 \mathrm{CHCl}_{3}\right)$.

(14) Heaney, H.; Ley, S. V. J. Chem. Soc., Perkin Trans. 1 1973, 499.

(15) Crystal data for 22: $\mathrm{C}_{15} \mathrm{H}_{17} \mathrm{NO}_{4}, \quad M=275.30$, orthorhombic, space group $P 22_{1} 2_{1} 2_{1}, a=7.2379(10), b=$ 11.5884(15), $c=16.677(2) \AA, V=1398.8(3) \AA^{3}, T=$ $150 \mathrm{~K}, Z=4, \mu(\mathrm{Mo}-\mathrm{K} \alpha)=0.095 \mathrm{~mm}^{-1}, 14225$ data measured using a Bruker APEX 2 CCD diffractometer with graphite-monochromated Mo-K $\alpha$ radiation 
( $\lambda=0.71073 \AA$ A). 2026 data were unique, $R_{\text {int }}=0.0329$; all unique data used in refinement against $F^{2}$ values to give final $w R 2=0.0885$ (on $F^{2}$ for all data), $R=0.0338$ ffor 1831 data with $F^{2}>2 \sigma\left(F^{2}\right)$ \}, absolute structure could not be determined from the diffraction data; Friedel pairs were merged $\}. \mathrm{H}$ atoms on $\mathrm{C}(6)$ had coordinates freely refined; all other $\mathrm{H}$ atoms were constrained. Programs used were Bruker SMART ${ }^{16}$, SAINT $^{16}$, SHELXTL ${ }^{17,18}$ and local programs. CCDC 838703 contains the supplementary crystallographic data for this paper. These data can be obtained free of charge from The Cambridge Crystallographic Data Centre via www.ccdc.cam.ac.uk/data_request/cif.

(16) SMART and SAINT software for CCD diffractometers, Bruker AXS Inc, Madison, WI, 2008.

(17) G. M. Sheldrick. SHELXTL user manual, version 5, Bruker AXS Inc., Madison, WI, 1994.

(18) Sheldrick, G.M., Acta Crystallogr. 2008, A64, 112-122.

(19) To our knowledge the only previous example of a single crystal X-ray structure of an unsubstituted chiral allenamide was reported by the group of Hsung (see, Tracey, M. R.; Grebe, T. P. Brennessel, W. W.; Hsung, R. P. Acta Cryst. 2004, C60, o830).

(20) To a solution of $22(100 \mathrm{mg}, 0.36 \mathrm{mmol})$ in $\mathrm{CH}_{2} \mathrm{Cl}_{2}(2$ $\mathrm{mL})$ at room temperature was added a $5 \mathrm{~mol} \%$ solution of $\mathrm{AuPPh}_{3} \mathrm{OTf}$. (NB. The $5 \mathrm{~mol} \%$ solution of $\mathrm{AgPPh}_{3} \mathrm{OTf}$ was prepared from the addition of $\mathrm{AuClPPh}_{3}(9 \mathrm{mg}, 0.018 \mathrm{mmol})$ to AgOTf $(4.7 \mathrm{mg}, 0.018$ $\mathrm{mmol})$ ) in $\mathrm{CH}_{2} \mathrm{Cl}_{2}(1 \mathrm{~mL})$ and the resultant suspension stirred for $10 \mathrm{~min}$. at room temperature). After $5 \mathrm{~min}$. the starting material was consumed after which the solvent was removed in vacuo. The crude product was then purified by column chromatography $\left(R_{\mathrm{f}}=0.25,1: 1\right.$ ethyl acetate - petroleum ether) to yield $\mathbf{2 3}$ as a colourless oil (98 mg, quantitative); $v_{\max }$ (solution, $\mathrm{CHCl}_{3}$ ) 3020, 2936, 1749, 1613, 1518, 1420, 1226, 1115 $\mathrm{cm}^{-1} ; \delta_{\mathrm{H}}\left(400 \mathrm{MHz} ; \mathrm{CDCl}_{3}\right) 6.62(\mathrm{~s}, 1 \mathrm{H}), 6.58(\mathrm{~s}, 1 \mathrm{H})$, $5.98-5.90(\mathrm{~m}, 1 \mathrm{H}), 5.29-5.24(\mathrm{~m}, 3 \mathrm{H}), 4.57-4.52(\mathrm{t}$, $J=8.4 \mathrm{~Hz}, 1 \mathrm{H}), 4.15-4.12(\mathrm{dd}, J=8.4,8.8 \mathrm{~Hz}, 1 \mathrm{H})$, $4.05-3.99(\mathrm{~m}, 1 \mathrm{H}), 3.89(\mathrm{~s}, 3 \mathrm{H}), 3.84(\mathrm{~s}, 3 \mathrm{H}), 2.83(\mathrm{~d}$, $J=7.7 \mathrm{~Hz}, 2 \mathrm{H}) ; \delta_{\mathrm{C}}\left(100 \mathrm{MHz} ; \mathrm{CDCl}_{3}\right)$ 156.7(C), 148.3(C), 148.0(C), 136.4(CH), 125.2(C), 127.7(C), 117.5 $\left(\mathrm{CH}_{2}\right), \quad 111.6(\mathrm{CH}), \quad 110.4(\mathrm{C}), \quad 68.5\left(\mathrm{CH}_{2}\right)$, 56.0 $\left(\mathrm{CH}_{3}\right), 55.9\left(\mathrm{CH}_{3}\right), 54.7\left(\mathrm{CH}_{2}\right), 48.6(\mathrm{C}), 33.8\left(\mathrm{CH}_{2}\right)$; HRMS $\mathrm{MNa}^{+}, \mathrm{C}_{15} \mathrm{H}_{17} \mathrm{NO}_{4}$, found 298.1044, requires $\mathrm{MNa}^{+} 298.1055 ;[\alpha]^{21}{ }_{\mathrm{D}}^{-160.8}\left(c 1.00 \mathrm{CHCl}_{3}\right)$. 
Sanjitpal Singh, Mark R. J. Elsegood and Marc C. Kimber*

An Au(I) catalysed allenamide cyclisation giving access to a $\alpha$-vinyl substituted tetrahydroisoquinoline building block

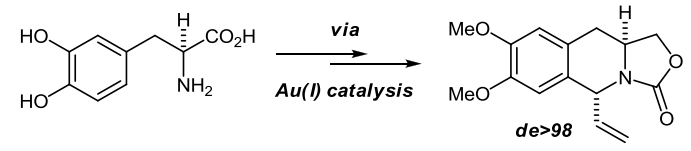

